\title{
New port development and global city making: Emergence of the Shanghai-Yangshan multilayered gateway hub
}

\author{
Chengjin WANG \\ Key Laboratory of Regional Sustainable Development Modeling \\ Institute of Geographical Sciences and Natural Resources Research (IGSNRR) \\ Chinese Academy of Sciences (CAS) \\ Beijing 100101, China \\ cjwang@igsnrr.ac.cn
}

César DUCRUET

French National Centre for Scientific Research (CNRS)

UMR 8504 Géographie-cités

F-75006 Paris, France

cdu@parisgeo.cnrs.fr

\begin{abstract}
Planned as Shanghai's new port, Yangshan is currently expanding its roles as transhipment hub and integrated logistics/industrial center in the Asia-Pacific region. This paper examines the impact of the emergence of Yangshan on the spatial pattern of the Yangtze River Delta since the 1970s, with reference to existing port system spatial evolutionary models. While this emergence confirms the trend of offshore hub development and regionalization processes observed in other regions, we also discuss noticeable deviations due to territorial and governance issues. Strong national policies favoring Shanghai's vicinity rather than Ningbo as well as the growth of Yangshan beyond sole transhipment functions all contribute to Shanghai's transformation into a global city.
\end{abstract}

Keywords: Asia; China; corridor; offshore hub; port system evolution; urban growth; Yangtze River Delta 


\section{Introduction}

Throughout the literature on port cities, a majority of the research provides a separate discussion on either port or urban functions. Port and urban specialists often focus on what may appear as processes and actors of distinctly different nature. One example is the large body of research on so-called port systems where neighbouring port nodes go through successive development phases marked by varying traffic concentration levels. Geographers have been particularly active in describing the spatial evolution of port systems where load centers and offshore hubs influence the port hierarchy due to their competitiveness and attractiveness in the transport and logistics chain at sea and on land (Fleming and Hayuth, 1994; Notteboom and Rodrigue, 2005). Yet, reference to the territorial aspects of these changes is generally kept minimal due to a central focus on transport players and flows.

This paper chooses another perspective that is to consider port dynamics as illustrations and components of wider urban transformation processes. Maritime ports have been recently recognized to be still important part of urban areas despite many changes in the distribution and operation of transport and value chains (Hall and Jacobs, 2012). Although ports and port terminals perform specific activities not always in accordance with their adjacent economy, they can usually be seen as one function among others in the wider urban fabric. Port cities are thus typical illustrations of local-global interactions taking place between territories, production networks, and commodity chains through physical transfers and sector-specific services (Hesse, 2010; Jacobs et al., 2010, 2011). Such port-cityregion relationships are particularly intense in Asia where urban and port issues are very much intermingled, which seem to be less significant in contexts such as Europe (Van der Lugt and De Langen, 2005; Lee and Ducruet, 2009). Many case studies confirm this fact. For example studies of Kaohsiung (Haynes et al., 1997), Busan (Frémont and Ducruet, 2005), Dubai (Jacobs and Hall, 2007), Hong Kong (Wang and Chen, 2010), and Incheon (Ducruet et al., 2012) all show that port dynamics are adapted to broader metropolitan processes. These adaptations may be changing as new types of nodes are emerging through a combination of transport, supply chain, logistics, and international trade activities (Palmer, 1999) which have created multilayered gateways ensuring multiple functions which together have new urban impacts.

To date little has been said about the case of Shanghai, which has developed as one of the 
world's largest seaports and global financial center. Research that has been done has most likely studied Shanghai's urban functions with reference to Pudong rather than its port (Yeung and Li, 1999; Wu, 2000; Yusuf and Wu, 2002; Cai and Sit, 2003; Wei and Leung, 2005; Lai, 2009), or ex plored its maritime functions barely mentioning its emerging global city functions (Wang et al., 2004). Exceptions have been the recent study by Huang (2009), questioning Shanghai's place as an Asian model city and the earlier study by Yan and Tang (1990) on the interdependence between port and urban growth in Shanghai's history. The coincidence of rapid urban and port growth in Shanghai thus deserves special attention. That attention will need to include insight on the evolution of global hub port cities, believed to exhibit certain similarities across Asia (Lee et al., 2008). In addition the rapid integration of China in global shipping and logistics networks has been well documented (Comtois, 1999; Cullinane, 2005; Yap and Lam, 2006) as well as the diffusion of containerization and the emergence of hub ports (Rimmer and Comtois, 2009; Cullinane and Song, 2007). Scholars have principally looked at Chinese ports such as port-FEZ bundles in Tianjin (Wang and Olivier, 2006), port development in the Pearl River Delta (Wang and Slack, 2000; Airriess, 2001), and traffic reorientation across the Yellow Sea (Lee and Rodrigue, 2006).Shanghai's prominence as main gateway for the Yangtze River has been well discussed in terms of port competition and corridor formation and insight has extended to include the current hinterland penetration of logistics networks across the Yangtze River Valley (YRV) (Cullinane et al., 2005; Veenstra and Notteboom, 2011). To date very limited attention has been paid to Yangshan, a gigantic new port project operating since 2005 which has lifted Shanghai into a new level of global activity.

Yangshan raises some problems and opportunities that reflect the coincidence between port expansion and global city formation. Beyond the sole provision of additional capacity and better technical standards, one main factor in the emergence of Yangshan is the difficulty for Shanghai to maintain and increase both its gateway (hinterland) and hub (maritime) functions at a single node. Such pressures are felt simultaneously at regional and local level and are expressed in the shift of some shipping activity away from the inner port (as in the spatial development model of Bird (1963)) and captured in port system evolution models (see Ducruet et al., 2009 for a synthesis). A dual system mixing hub and gateway functions is thus emerging in contrast to more classic experiments of new port development elsewhere. Another factor central to Yangshan's influence upon Shanghai is highly political, as seen in problems of cross-border governance among different provincial jurisdictions. Here its 
experience is shared with other Asian port cities such as Busan and Incheon in South Korea (Frémont and Ducruet, 2005; Ducruet et al., 2012), Hong Kong and Shenzhen (Song, 2002), and some other peripheral port developments in Asia (Slack and Wang, 2002). These two dimensions emerge as growing global cities emphasise the control of physically grounded port and logistics functions in a competitive context, and how port dynamics, in turn, can foster economic activities beyond sole transhipments. It is the interdependencies between these two aspects that provide the agenda of the research reported in this paper.

The remainder of the paper is as follows. Section 2 describes the evolution of the entire YRD port system since the early 1970s in the light of port system evolutionary models. Section 3 analyzes with more scrutiny the deviations from the models, with a special focus on the emergence of Yangshan new port in terms of (trans-)port governance, urban and regional planning, economic development problems and opportunities. Conclusions are proposed in section 4 about the lessons learned from this case study for further research on port system evolution.

\section{Port system evolution in the Yangtze River Delta (1970-2010)}

Since the 1960s, a wide-ranging literature has provided a number of port system evolutionary models and applications, recently classified by Ducruet et al. (2009) into concentration and de-concentration factors. Although such ideal-typical approaches remain limited in explaining particular cases and contexts (Weber, 2004), they are used in this paper to help reveal local deviations caused by specific territorial and governance issues and to facilitate comparisons with other port systems worldwide. Although recent studies of Hong Kong (Wang, 1998) and peripheral port challenges in Asia (Slack and Wang, 2002) question the mechanical character of port system evolutionary models, the same authors recognized that trends affecting Pearl River Delta ports "are being replicated elsewhere" (Wang and Slack, 2000, p. 263). Figure 1 provides a synthesis of stylized phases affecting a container port system, with reference to the pioneer model of Taaffe et al. (1963) and to the recent synthesis of other classic models by Notteboom and Rodrigue (2005). The latter notably added a sixth phase about the emergence of an offshore hub that is relevant to the development of Yangshan port. Each phase has a generic sequence, which when compared to actual outcomes can detect deviations caused by local particularities. To provide a starting point for an analysis along these lines Figure 2 provides key traffic data by port and by period for the 
Yangtze port hierarchy.

[Insert Figure 1: Spatial evolution model of a container port system] [Insert Figure 2:

Evolution of the YRD port hierarchy, 1979-2010]

\subsection{Pre-containerization and containerization experiment (1970s)}

Before the 1970s, the port system in the YRD was in the phase of pre-containerization. Shanghai possessed locational advantage being at the junction of different transport networks, namely river and maritime shipping as well as north-south coastal shipping, and it became the main port of this region and even of the whole mainland China. In 1972, Shanghai handled about $72.1 \%$ of YRD's total traffic, conferring a high traffic concentration level to one port within a system, which greatly differs from the generic model where the first two phases represent a homogenous distribution between many ports with only a slight concentration on one main port. Shanghai also became the largest trade-gateway port and its international traffic accounted for $22 \%$ of its total traffic. Meanwhile, as the largest river ports in the YRD, Nanjing and Wuhu ports shared $13.6 \%$ and $6.5 \%$ of YRD's total traffic respectively. Other ports such as Nantong, Anqing, Tongling, Zhenjiang, Chizhou, Maanshan, Jiangyin, and Gaogang handled much less traffic, The observed spatial pattern is consistent with the pre-containerization phase of the model, with the notable difference that smaller ports have not experienced much development, for two main reasons. First, the north side of the Yangtze River estuary is an alluvial coast with poor physical conditions in terms of port construction. Second, before the 1970s, the planned economy resulted in limited maritime trade and lesser need for the development of seaports in North Zhejiang.

Since the early 1970s, YRD ports welcomed containerization (Figures 2 and 3). Coastal container shipping extended firstly from Shanghai to Dalian in 1972, and further extended to Nantong port. Subsequently, Shanghai launched another experimental shipping of twenty-foot containers through foreign bulk cargo ships to US ports in 1974. Between 1973 and 1975, China as a whole realized 89 shipments totalling 2,499 containers in such fashion. However, all these experiments remained under Chinese container technology standards. International standards for container shipments at Chinese ports only started in the mid1970s. In 1977, Shanghai port imported large and small forklifts as well as trailers from Japan, thereby becoming China's first port to handle international standard containers. 
Subsequently, international container shipping routes from Shanghai to Japan and Australia were opened in 1978 using what were originally bulk cargo vessels. The same year, Shanghai, Tianjin, and Qingdao ports handled 18,000 TEU altogether. The period 1972-1978 thus marks the phase of containerization experiment concerning Shanghai, Nantong, and Nanjing in the YRD. This confirms that containerization favored the largest ports first and spread through a hierarchical diffusion process. However, the lack of specialized handling facilities prevented higher traffic levels at traditional port terminals. Therefore, the introduction of container technology greatly favored traffic concentration in Shanghai at the expense of other ports, So a major difference between the actual outcome and Figure $1 \mathrm{was}$ probably due to the way the controls of a centralized economy shaped shipping patterns.

\subsection{Spread of containerization (1980s to mid-1990s)}

In the late 1970s, the port system moved beyond the experimental phase and entered international container shipping. Since the early 1980s, the reform and a policy to open up the economy promoted the development of export-oriented industries in the YRD, resulting in a rapid increase of containerized cargoes and the popularization of container technology (Figures 3 and 4). The container shipping route from Shanghai to the United States was launched in 1980, followed by other full container shipping routes to Japan, Europe, and West Africa. In addition, domestic shipping routes also developed, such as Dalian-Shanghai and YRD-Hong Kong. In 1983, Shanghai port reached a total traffic of about 80,000 TEUs. This success rapidly motivated other ports to apply this technology, such as Zhangjiagang in 1983, Nantong, and Nanjing in 1984. Zhangjiagang handled about 33,000 TEUs in 1986, and after the operation of Yangtze River shipping route from Shanghai to Wuhan in 1984, over 20 container shipping routes started their operations throughout mainland China, including river, coastal, and deep-sea shipping. An increasing number of ports developed international container shipping, such as Ningbo and Haimen in 1988, Anqing, Zhenjiang, Zhoushan, and Wuhu in 1990, Jiangyin in 1994, and Gaogang in 1995. Shanghai acquired a leading role through constructing numerous terminals along the Huangpu River (i.e. Zhanghuabang, Jungonglu, Gongqing, Zhujiamen, and Longwu) and the south bank of Yangtze River (i.e. Baoshan, Luojing, and Waigaoqiao) providing the infrastructure to tranship containers along the emerging Yangtze corridor.

Such feeder traffic with Shanghai represented about $20 \%$ of Nantong and Zhenjiang's total 
traffic in 1995, and 10\% of Zhangjiagang and Nanjing's total traffic. New land-based transport systems connecting major seaports developed as well, such as the Shanghai-Nanjing and Shanghai-Hangzhou expressways, in order to improve hinterland accessibility. The destinations of international shipping expanded to include Hong Kong, Japan, North American ports and Australia. This period witnessed certain similarities with the model as earliest adopters of containerization concentrated most traffic and became the dominant ports. As suggested by Figure 4, traffic concentration levels have been irregular from the early 1980 s to the mid-1990s, suggesting the spread of container technology outside Shanghai.

\section{[Insert Figure 3: Container traffic evolution, 1979-2010]}

\subsection{Container hub port and concentration (mid-1990s to 2005)}

Since the late 1990s, the YRD port system experienced a growing concentration at a few ports as can be seen in the trends in the Gini coefficient and the Herfindahl-Hirschman Index (HHI) in Figure 4 before stabilizing in the early 2000s, even though there was an increase in the number of ports. Concentration and de-concentration thus go together, as seen with the lowering traffic concentration at Shanghai. Indeed around 2000, 85\% of YRD ports possessed container technology and handled about 7.25 million TEUs. Shanghai then handled 5.61 million TEUs, accounting for $77.4 \%$ of the YRD's total traffic, notably due to its concentration of most shipping routes to Hong Kong and Japan and to the polarization of a hub-feeder system for canal and river trade. Other ports started international services, such as Taizhou and Yangzhou in 1996, Zhapu in 1997, Changshu in 1998, Sheyang in 1999, and Changzhou, Hangzhou, Maanshan, and Taicang in 2000. Such parallel trends explain the stabilization of the number of ports in the 2000s and the subsequent decrease of concentration in the YRD. Yet, Shanghai maintained a strong polarization of flows as it benefited from Chinese government strategy to reinforce its role as an international shipping centre. Shanghai's shipping activity thus reached 1,494 monthly schedules of containerships in 2004, of which 279 are international and 416 are coastal, and handled14.55 million TEUs.

Such evidence somewhat contradicts the fourth phase of the model characterized by the dominance of one single gateway. For instance, Ningbo enjoyed high yearly growth rates of over $30 \%$ while attracting 115 shipping routes and 500 schedules a month. The growth of 
Ningbo occurred in parallel with the decline of other medium-sized ports such as Nantong, Nanjing, and Wuhu, due to less dynamic local economic development (Veenstra and Notteboom, 2011) and traffic limits associated with river transport compared with truck transport. The development of a domestic hub-feeder system centered upon Shanghai illustrates the latter's hinterland expansion (i.e. Jiangsu, Zhejiang, Anhui, Jiangxi, Hunan, Hubei, Chongqing, and Sichuan) on the level of the Yangtze River Valley (YRV) backed by new expressway and railway services as well as the dredging of the Yangtze River and the Great Canal. Feeder cargo from the YRV accounts for 50\% of Shanghai's total traffic (excluding traffic related with the supply of Shanghai city itself) (see Figure 5). Shanghai polarizes a major share of some inland river ports such as $80 \%$ and $48 \%$ of Jiujiang and Nanjing's container traffic respectively. Shanghai notably strengthened its gateway position by building logistics bases in the YRV and purchasing shares of inland ports to a level of $40 \%$ in Chongqing, 55\% in Wuhan, and 25\% in Nanjing, while also cooperating with Wuhu, Taicang, Nantong, Jiangyin, and Wenzhou. Several small river ports such as Changsha, Nantong, and Yangzhou also became Shanghai's feeder ports. This trend to widen and deepen the catchment zone only partly matches the generic model as hinterland expansion occurred much earlier compared with the sixth phase of Taaffe et al. (1963)'s model labelled the emergence of high-priority main streets.

\section{[Insert Figure 4: Number of container ports and traffic concentration] [Insert Figure 5: Feeder traffic between Yangtze River ports and Shanghai]}

\subsection{Emergence of the offshore hub (2005)}

With the growth of traffic, Shanghai port faced important local limitations on its further ${ }^{1}$ development, such as the growing size of vessels requiring deep-water access at terminals. Such constraints could lead to a decentralization phase (Rimmer, 1967a, 1967b) that is similar to the challenge of the periphery (Hayuth, 1988) whereby large and congested gateways lose traffic to secondary ports. This could be facilitated by changes in shipping deregulations enabling transport players to focus more on service cost and quality rather than on the size of infrastructure (Slack, 1985; $\mathrm{Ng}, 2006$ ). In this way a secondary port with poor hinterland access but good nautical accessibility can become the focus of important traffic

\footnotetext{
${ }^{1}$ Zhanghuabing terminal and the Huangpu River were limited by a water depth of 7-8 $\mathrm{m}$ thus not allowing the entrance of vessels beyond 1,400 TEUs capacity.
} 
gains depending on the availability of cheap land for terminal construction. To ward off these threats a so-called offshore hub can be developed in the vicinity of the large gateway and so maintain the significant role of the port while meeting the needs of the international carriers and terminal operators (Baird, 2003). The main gateway may compensate the shifts of container services to the offshore hub by expanding its involvement in the logistics integration of the hinterland and also via increased activity at dry ports (Palmer, 1999), as seen in the regionalization phase described by Notteboom and Rodrigue (2005). At the same time, the offshore hub can develop value-added activities in relation to a local cargo base (Rodrigue and Notteboom, 2010).

Although the regionalization process started earlier than in the models, as seen in the previous discussions, the construction of Yangshan new port well fits with the phase of diffusion and offshore hub. Constructed since 2002 and starting its operations in 2005, Yangshan is located on the eponym island at the junction between Yangtze River shipping and maritime shipping, with a shoreline of about $20 \mathrm{~km}$ and a water depth of over $15 \mathrm{~m}$. A total of 50 deep-water berths can accommodate vessels of 8,000 TEUs and over. Besides such technical capabilities, Yangshan is connected to mainland by truck through the Donghai Bridge or by other ports through shipping and railway ${ }^{2}$.

In China, central and local governments traditionally hold high control over the port industry. The main developer of Yangshan port, Shanghai Tongsheng Investment Co. Ltd (STI), is jointly owned by three main players, namely Shanghai International Group Co. Ltd (SIG), Shanghai Port Administration Bureau (SPAB), and Shanghai State-owned Assets Operation $\mathrm{Co}^{3}$ (see Figure 6). The first phase of the project was largely supported by the central government and was completed by Shanghai firms such as Shanghai Port Building Group. In June 2002, STI was offered 7.5 billion Yuan in loans for the first-phase construction by one consortium of five domestic banks and five other lending institutions. This consortium signed a deal to provide a 17 billion Yuan credit line for the port construction up to 2020. In consideration of the importance of Yangshan port for China's economy, the main stakeholders relied on themselves during this first phase of port

\footnotetext{
${ }^{2}$ Donghai Bridge is $32.5 \mathrm{~km}$ in length and 31.5 meters in width with six traffic lanes two-way. The annual navigable capacity under the bridge is over 5 million TEUs.
} 
construction. However, the port's excellent natural conditions and geographical location motivated many foreign investors to participate in the project, as in many similar projects of new port development (Baird, 2003).

By promulgating a document called Provisions on Guiding Foreign Investment Direction in 2002, the central government allowed foreign investors to establish joint ventures with domestic firms and even to reach a majority share. China's agreement with the World Trade Organization allows foreign investors to own a maximum of $75 \%$ share in port construction projects. Overseas shipping giants such as Maersk, China Ocean Shipping (Group) Company (COSCO), Orient Overseas Container Line (OOCL) as well as global terminal operators such as APM Terminals, Hutchinson Whampoa, and PSA Singapore Terminals directly expressed their interest in the second phase of the project. The second phase was completed jointly by Hutchison Whampoa, Maersk, COSCO, China Shipping Container Lines (CSCL), and Shanghai International Port Group (SIPG). The currently ongoing third phase already attracted many investors such as Maersk, Hutchison Whampoa, APM, and Dubai Ports World. This gradual opening to foreign players is believed to improve the efficiency of port infrastructures and operation as well as the management level.

\section{[Insert Figure 6: Governance structure of Yangshan port]}

Foreign players remain restricted in several aspects, however. For instance in 2007, SIG accepted to be placed under the authority of STI to operate and manage the construction of the third phase. Another example is SPAB imposing several guidelines to the selection of partners, such as the financial situation of the firm, its performance record as terminal operator, its ability to attract more shipping lines and to set up more routes, and its relationship with Shanghai. Such elements illustrate China's will to remain self-sufficient during the first steps of the construction process in order to avoid the domination of individual port operators. Even when attracting foreign investors, Chinese authorities maintain a complex structure of terminal ownership and stakeholder community, under a single port administration. In addition, one visible trend is the gradual shift from a structure dominated by terminal operators to a structure dominated by a variety of major shipping

\footnotetext{
${ }^{3}$ The stock share of Shanghai Tongsheng Investment Co. (created in 2002) is owned by three main players, namely Shanghai International Group Co. (52\%), Shanghai Port Administration Bureau (40\%), and Shanghai State-owned Assets Operation Co. (8\%).
} 
lines (Wang et al., 2004), some of them being Chinese. For instance, phase 2 of Yangshan port construction welcomed investments from Hutchison Whampoa (32\%), Maersk (32\%), SIPG (16\%), COSCO (10\%), and CSCL (10\%) through the joint venture called Shanghai Yadong InternationalContainerco.Ltd.Similarly,thethirdphase(partA)received investments from PSA (30\%), CMA-CGM (10\%), CSCL (30\%), and SIPG (30\%), thus demonstrating a growing share of foreign (global) players. Yet, part B of the third phase depends entirely upon the investment from Shanghai Guangdong International Container Terminal Co., which is also owned by SIPG. In parallel, there is a reinforcement of the SIPG during the completion of the project, as the group acquired progressively several other companies responsible for the construction of Donghai Bridge (Shanghai Tongsheng Bridge Construction Co. Ltd in 2002), the Yangshan bonded area (Shanghai Tongsheng Logistics Park Investment and Development Co. in 2002), and Yangshan port first two phases (Shanghai Shengdong International Container Terminal Co. Ltd in 2005).

After six years of feasibility studies, the project of Yangshan port and Donghai Bridge was approved by China's State Council, and was planned to be constructed over three phases (see Table 1). The first phase started in 2002 and was completed in 2005, comprising port terminals on Yangshan Island, the Donghai Bridge ${ }^{4}$, the Hulu Expressway, and supporting infrastructures in Luchao city. This phase covers a port area of about 1.53 square $\mathrm{km}$ equipped with five container berths, totaling 1,600 $\mathrm{m}$ of quays and a storage yard of 720,000 square meters. The water depth of berths reaches $15.5 \mathrm{~m}$ to accommodate the fifth and sixth generation vessels, with an annual handling capacity of 2.2 million TEUs. The second phase started in 2006 added 4 deep-water berths and another 2.1 million TEUs capacity. At present the two first phases are completed with nine berths totaling $3 \mathrm{~km}$ of quay length. The third phase is planned to add seven berths and 4.7 million TEUs capacity, while according to the master plan the whole project shall be fully completed by 2020 , with about 30 deep-water berths having a total handling capacity of 15 million TEUs.

\section{[Insert Table 1: Construction phases of Yangshan port]}

\subsection{Diffusion and regionalization (since 2005)}

\footnotetext{
${ }^{4}$ Constructed by Shanghai Tongsheng Bridge Construction Co. Ltd, acquired by Shanghai International Port Group CO. Ltd in 2002.
} 
Consistently with the discussion by Lemarchand and Joly (2009) on the bigger growth rates of emerging ports compared with more mature ports, Yangshan rapidly increased its traffic within a few years (Figure 7), reaching 8.23 million TEUs in 2008, of which $48 \%$ was river shipping (against $43.1 \%$ in 2010) and 8-9\% for international transhipment ${ }^{5}$, the rest being related with hinterland traffic through trucking over the Donghai Bridge. With reference to the model, we see that one crucialdimensionofthisdevelopmentphaseisthecodevelopmentofthemain gateway port and of the offshore hub through a mixture of deep-sea and short-sea services, thus taking the form and function of a dual hub and gateway. Such duality has been observed by Wang and Chen (2010): "Spatially, it has been evident that dual hub port systems appear in megacity regions such as the ports of Hong Kong and Shenzhen" but also Singapore and Tanjung Pelepas, Busan and Gwangyang. As seen in Figure 8, Shanghai's traffic decreased in recent years from 20.04 million TEUs in 2007 to 18 million TEUs in 2010. The global financial crisis had direct impacts on the level of shipping activities as it even decreased to 16.5 million TEUs in 2009. As Yangshan's traffic continues to grow and reached about 10 million TEUs in 2010, the combined traffic of Shanghai and Yangshan overtook Hong Kong as the world's second biggest container port. Yangshan's market share in the YRD steadily increased from $13.8 \%$ (2006) to $34 \%$ (2009) and $35.7 \%$ (2010), while Shanghai's market share comparatively diminished from $86.2 \%$ (2006) to $64.3 \%$ (2010). Shanghai's relative decline is also attributed to Ningbo's rapid growth into a deepwater port since the 1990s as discussed previously (see Figure 9). Traffic shifts from Shanghai to Ningbo contribute to narrow the gap from 13 to 5 million TEUs between 2005 and 2010.

\section{[Insert Figure 7: Container traffic evolution at Yangshan port since May 2006] [Insert Figure 8: Container traffic evolution at Shanghai, Yangshan, and Ningbo]}

Yangshan's main activity is transhipment and it has diverted Shanghai's deep-sea traffic as well as feeder traffic with Yangtze River ports. Numerous alliances and ocean carriers shifted their services from Shanghai (Waigaoqiao) to Yangshan, such as CKYH (Asia-USA), Hamburg Süd, Mediterranean Shipping Company (MSC), Mitsui O.S.K. Lines, APL, and OOCL. In 2010, Yangshan was included in no less than 9 trunk routes with links to more

\footnotetext{
${ }^{5}$ Sea-river transshipment corresponds to traffic from the YRD to Yangshan port that is transshipped towards other Chinese mainland ports, Hong Kong, and/or foreign ports, while international transshipment is the traffic originating from overseas transiting through Yangshan port.
} 
than 300 ports and 90 weekly schedules operated by 28 carriers, while short sea services (i.e. intra-Asian) concentrated at Waigaoqiao, Zhanghuabang, and Jungonglu. At present, Yangshan welcomes 900 to 1,100 container vessels monthly, of which one-third are on international trading routes. Traffic patterns were also modified along the Yangtze corridor as 26 carriers opened 17 feeder routes between river ports and Yangshan. Such riverborne traffic is provided daily by 62 vessels, which account for $34.5 \%$ of Yangshan's total traffic. Nowadays about 13 shuttle vessels and 4-5 daily schedules are provided between Yangshan and Waigaoqiao. The Taicang-Yangshan service is operated with 250 TEU vessels since 2005, while the Nanjing-Yangshan and Nantong-Yangshan services operated by Mitsui O.S.K. Lines and Sinotrans were launched in 2006 with 17 and 4 weekly schedules respectively. From May 2006 a direct river shipping service from Wuhan operated by COSCO shifted destination from Waigaoqiao to Yangshan. Such nonstop services were officially systematized in 2008 with the Navigation Technological Conditions for Specific Routes issuing special permit to vessels passing through the Yangtze River Estuary towards Yangshan.

With the development of logistics networks and deep-water ports, the YRD has experienced a continuation of the port regionalization phase. Several cities in the YRD have built new logistics facilities as seen in numerous logistics parks in Shanghai (8), Suzhou (10), and Nanjing (4) as well as in Changzhou and Wuxi. Dedicated rail services have been established between Shanghai and the hinterland (e.g. Nanjing, Chengdu, Hefei, Bengbu, Changsha, Xi'an, Zhengzhou, Chongqing, Yiwu, Wenzhou, Ningbo, Nanchang, and Zhuzhou). Most cargo moves a short distance; the cargo coming from YRV currently accounts for $95 \%$ of Shanghai's rail-sea integrated traffic. This is supported by growing traffic flows over the Donghai Bridge ${ }^{6}$ by truck (see Figure 9). Numerous carriers, shippers, and forwarders have also spread their offices across this vast hinterland, and companies such as COSCO, Orient Overseas Container Lines (OOCL), Sinotrans, American President Lines (APL), K-line, ZIM, Hanjin, and Nedlloyd now have offices in other YRD cities inland. Such dynamics are backed by efforts to better integrate the corridor, notably through the merging of port authorities ${ }^{7}$, the

\footnotetext{
${ }^{6}$ Since the opening of Donghai Bridge, truck traffic of containers has increased continuously from 1.5 million TEUs in 2006 to 3 million TEUs in 2008. Trucks transfer containers from the railway station of Luchao port which connects 14 cities (e.g. Hefei, Nanchang), but also from the YRD to overseas. In 2008, truck (hinterland) traffic accounted for about 3.23 million TEUs (39.3\%) in Yangshan's total port traffic reaching 8.23 million TEUs. No congestion problems have been so far reported on the bridge. While container trucks do not pay the expensive bridge toll, it is not the case for other cargo trucks of passengers vehicles.

${ }^{7}$ Taicang, Changshu, and Zhangjiagang were merged into one single Suzhou port authority in 2002.
} 
purchasing of port infrastructure and stocks by carriers and terminal operators, the joint planning of bonded areas across the YRD (i.e. Yangshan, Waigaoqiao, Ningbo, Zhangjiagang, and Suzhou), and the redirection of local flows ${ }^{8}$.

\section{[Insert Figure 9: Container traffic by truck over Donghai Bridge, 2006-2009]}

At the East Asian level, although Shanghai's handling capacity in the early 2000s was comparable with other major hub ports, its transhipment function has remained secondary compared with traditional hub ports being Busan, Hong Kong, Kaohsiung, and Singapore. Recent studies on East Asian and Northeast Asian liner shipping networks demonstrated the relatively limited centrality of Shanghai in 1996 and 2006 (Ducruet et al., 2010) with regard to the domination of traditional hub ports and despite the rise of several other secondary ports such as Incheon, Port Klang, and Surabaya. Despite their impressive growth in traffic volumes, Chinese ports as a whole did not experiment equivalent centrality growth within East Asia, largely due to a late entry into the transshipment market. Indeed, Shanghai's transshipment ratio remained around $23.4 \%$ of total traffic in 2005 , while the international transshipment ratio represented 2.2\%: the latter reached 5.7\% in 2009 although the 11th fiveyear plan predicted a level of $10 \%$. International cargoes are thus generally transshipped via foreign hubs. For instance, about $40 \%$ of Busan's traffic is fed by transshipment with Chinese ports, which represents 2 million TEUs annually. Such evidence confirms that Shanghai's port development has so far been driven by hinterland-related dynamics rather than hub-related dynamics. It is thus too soon to predict whether or not Yangshan will take over the transshipment flows of traditional Asian hub ports. In terms of logistics performance however, Shanghai has already been seen as more competitive than Hong Kong and Kaohsiung in terms of cost, market, and industrial factors ( $\mathrm{Lu}$ and Yang, 2006). The main question is thus about whether Yangshan itself may develop purely port/transport functions or additional port-related and urban functions.

\section{The metropolitan dimension of port dynamics}

\footnotetext{
${ }^{8}$ Yangshan and Luchao are planned to strengthen mutual traffic by attracting cargo from South Jiangsu (Suzhou, Wuxi, and Changzhou) and North Zhejiang (Huzhou, Jiaxing, and Hangzhou) through Sushen, Dalu, Hangshen lines and the Huangpu River. Pudong railway will extend northward to Waigaoqiao and will connect Beijing, Nantong, Zhenjiang, and Jiaxing through Shanghai. Yangpu station in the urban core will shift its traffics to Luchao in order to avoid congestion.
} 
The evolution of the YRD port system in relation to Shanghai witnesses several deviations from the generic model presented in Figure 1 and used as a benchmark. While such differences were expected and can be largely attributed to the national factor of a rapid transition from a command economy to market-oriented economy, a more in-depth analysis of local factors remains necessary in order to fully understand the role of territorial and governance issues.

Firstly, recent logistics development in and around Shanghai must be understood bearing in mind wider functional and spatial shifts within metropolitan Shanghai. In 1986 and 1992 Shanghai was designated by the State Council to become China's largest urban, economic, technological, trading, financial, information, culture, and maritime centre, an objective that is reflected in subsequent rapid FDI growth since then (Wei and Leung, 2005). Several large-scale and complementary projects $^{9}$ were launched to achieve such objectives by which Shanghai's economy would shift from traditional industrial functions ${ }^{10}$ to international higher-order economic functions. Yet, with about 9.1 million people residing in Shanghai's inner city nowadays and a very high urban density, lack of space and congestion issues became paramount, taking the form of land-use tensions between industrial, port, and service activities. Early planning measures since the 1980s had the effect of moving industries and related port terminals (e.g. coal, oil, and sand) from the Wusong estuary to the south coast of Yangtze River estuary, notably by constructing the first container berth in Waigaoqiao. Current measures have prolonged such shifts by supporting the attraction of modern service industries at the urban core, and high-tech industries between the two main ring roads, while moving heavy industries and manufacturing plants towards suburban industrial parks ${ }^{11}$.

\footnotetext{
${ }^{9}$ Pudong zone, Lujiazui Financial and Trade Zone, Waigaoqiao Bonded Area, Jinqiao Export Processing Zone, and Zhangjiang Hi-Tech Park.

${ }^{10}$ In $1994,18.1 \%$ of Shanghai's inner city built-up area was devoted to industrial uses (20\% on the level of the metropolitan area), $8.6 \%$ to warehousing, and $3.4 \%$ to other private services. In the early 2000s Shanghai was still characterized by a strong dependence on manufacturing (50\% of total employment, against $27 \%$ in Taipei, 22\% in Singapore, 18\% in Tokyo and $8 \%$ in Hong Kong) a low car ownership and a low density of roads but with higher carbon emissions than most large Asian cities except Bangkok, and the highest rate of respiratory diseases among large Asian cities. FDI between 1979 and 2000 remained dominated by manufacturing (Wei and Leung, 2005).

${ }^{11}$ The urban core comprises the Huangpu and Nanshi districts for finance and trade, a second area between the two main ring roads includes Xuhui and Luwan districts for high-tech and culture, Jing an, Changning, and Putuo districts for business, logistics and education, Zhabei, Hongkou, and Yangpu districts for technological and urban industry, and the third area outside the second ring road is made of Baoshan, Minxing, and Jiading districts ensuring industrial base activities, of Jinshan, Songjiang, Fengxian, Nanhui, Qingpu, and Chongming districts mainly focusing on agriculture, industry, and tourism, and 10 "new towns" (Baoshan, Jiading, Songjiang, Jinshan, Minxing, Qingpu, Nanqiao, Huinan and Chengqiao as well as Luchao port city).
} 
Secondly, some of the new projects are both supporting and competing with Shanghai through attempts to exploit proximity within the global city (Figure 10). As recalled by Wei and Leung (2005, p.19), "in emerging global cities, such as in Shanghai, CBDs are usually weak, and often several emerging nodes compete with each other for preferential policies and foreign investment". Such trends directly reflect the ambitions of the 1999-2020 Masterplan launched by Shanghai Municipality that aims to de-concentrate the urban core through the establishment of new cities in other districts (see Figure 10). Luchao port city, situated at the southeast corner of Shanghai's urban area is planned as a new urban nucleus potentially rivaling central Shanghai in terms of global urban functions. Luchao is planned as the administrative base of Yangshan port by providing comprehensive functions including container distribution and storage, offshore processing, shipping market, residential, financial and commercial services, amenity and tourism. Third, the Hulu Expressway is another crucial element which connects Donghai Bridge with the hinterland and bypasses the old urban core. Another important traffic line is Pudong railway, with a first phase completed in late 2005 connecting Luchao, Shanghai-Hangzhou, Shanghai-Beijing, and providing fast access to the national railway network. The Yanshan project thus had important impacts on the layout of transport networks, since traffic shifted gradually from Yangpu station (closer to Shanghai's CBD) to Luchao station, which possesses anannualhandlingcapacityof 1.72millionTEUs.A significant issue in the urban context is the fact that Yangshan Island falls under the jurisdiction of the neighboring Zhejiang province. This has exacerbated tensions about local benefits. As underlined by Wang and Olivier (2003, p. 48), "never [in China] had a port authority built a container terminal situated outside its own boundaries". However, it was decided by the central government that while Yangshan port would belong to Zhejiang province, its management and administration would belong to Shanghai ${ }^{12}$. Nevertheless, Shengsi county (Zhejiang) plans to develop a new city on Yangshan island performing business, culture, leisure, tourism, and housing activities. Another issue concerned the role of Ningbo. This port would have been a suitable location for welcoming deep-sea terminals, with a water depth of about $18.2 \mathrm{~m}$ in Beilun

\footnotetext{
${ }^{12}$ Zhejiang province's early expectations levying taxes on Yangshan port operations confronted the fact that Shanghai Tongsheng Investment Co. Ltd (STI) registers in Shanghai. Yet, the Shengsi county, where Yangshan port locates, in Zhejiang province, is allowed to get a small share of taxes. Such tensions fostered Zhejiang province's investments on Ningbo port to compete with Shanghai and Yangshan ports. In addition, Shengsi county uses Yangshan port as a tool for competing with nearby Luchao harbor city through the attraction of large companies (Australia, Germany, Japan, and also Shanghai) for designing Yangshan new city with a capacity of 50 to 60,000 residents.
} 
harbor, the Chinese government preferred locating new investments nearer to Shanghai as a means consolidating Shanghai's international shipping center.

Thirdly, Yangshan was planned by the Chinese government as a value-added and integrated industrial, logistics, and shipping complex rather than a sole transhipment node. The Yangshan Bonded Port Area (YBPA) ${ }^{13}$ is a multimodal logistics centre for transhipment, distribution, insurance, finance, and entrepôt trade. This facility is designed to provide a local manufacturing base limiting truck and shipping flows to and from mainland China in addition to its first transhipment function. Up to 2008, 63 foreign companies have registered in this area, including third party logistics (e.g. Maersk, CTW, ProLogis, DSV A/S, BoConcept A/S),storage, manufacturers (e.g. non-ferrous metals, electronics, automobile parts) ${ }^{14}$, and carriers (e.g. Sinotrans, COSCO, Maersk). The total gross value of the bonded supervised goods in Yangshan reaches a total of US\$ 4.23 billion. Domestic cargoes fall under the same customs, tax, and currency exchange procedures than foreign goods. Registered companies are exempted from business taxes if they engage in shipping, transportation, loading and unloading, and storage. A cooperation across the YRD makes it possible for registered companies to declare at any of the 69 customs offices in mainland China. Crude oil and liquefied natural gas terminals are also being built.

\section{[Insert Figure 10: Location of map of Shanghai, Yangshan and Ningbo]}

The Shanghai-Yangshan dual hub in fact fully participates to the building of a global city, a process in which the reorganization of physical infrastructure and flows is a major factor. Such strategy even takes the form of a "multimodal tri-hub" including seaport, airport, and many centers (i.e. trade, financial, technical, information, tourism, and industrial) such as Lujiazui in Pudong, Waitan in Puxi (finance), and Zhangjiang (high-tech). Shanghai itself hosts the headquarters of China's three largest carriers (COSCO, CSCL, Sinotrans Shipping) and of 20 global shipping lines, 66 international carriers, 630 ship agencies, and 350

\footnotetext{
${ }^{13}$ YBPA was approved by the State Council in 2005 as China's first bonded port following the Reply of the State Council on Approval of Establishing Yangshan Bonded Harbor District and Directory of Industrial Development and Investing Policies in Yangshan Bonded Zone. It covers 8.14 square kilometers including an export processing area, a bonded area, and the port area itself, providing storage and supervision of import and export cargo, processing of imported raw materials and semi-finished goods as well as reprocessing, assembling and exporting components.

${ }^{14}$ Yangshan was notably selected by large companies such as Alcatel-Lucent (Asia-Pacific integrated logistics centre), Ericsson and Pioneer (processing and distribution base), WSP Italy and Chrysler (automobile storage and logistics centre), Zhongchu Development Stock Co. and GKE (metals).
} 
international freight forwarders. Luchao port city provides not only shipping-related services but also urban functions (i.e. residence, leisure, education and training) as well as industrial functions (equipment manufacturing industry, industrial park, export processing), thus becoming a new growth pole in Shanghai.

\section{Conclusion}

The current transformation of Shanghai into a global city is in many ways similar to other development paths occurring in other large Asian port cities. However, Shanghai remains unique with regard to the crucial importance of the Yangtze River Delta (YRD) that developed since the 1970s as a corridor and gateway connecting China with the rest of the world, thereby conferring Shanghai specific logistics and multimodal functions for hinterland control. While those maritime and logistics functions fully influence the formation of a global city, they also exhibit particular trends and contribute to reinforce Shanghai's specialization in certain economic sectors. A large portion of urban space is devoted to physical infrastructure of which port terminals and related industrial and service activities ensuring cargo transfers. These have been accommodated within a broader metropolitan region; elsewhere the lack of space and fierce competition among East Asian ports fostered the expansion of facilities beyond the urban core, thus creating tensions among local authorities. Although the evolution of the YRD port system matches, overall, general models of port system evolution, significant deviations are observed.

First, the distribution of container flows among YRD ports was already strongly concentrated upon Shanghai in the early phases, while the regionalization phase has started earlier than in the generic model. This can be attributed to three complementary factors: a specific context where the diffusion of containerization has been more selective during the transition from command to market economy, a crucial importance of river shipping facilitating rapid hinterland penetration in contrast to limited road and rail infrastructure over long distances, and a rather aggressive strategy of hinterland control by Shanghai port management by securing inland terminals for feeder traffic and centralizing decision over freight distribution patterns. Second, strong support from the central government to Shanghai's globalization favored Yangshan new port rather than existing neighboring ports (i.e. Ningbo) for infrastructure expansion and offshore hub development. This strong role of the central government has minimized some potential tensions arising from rent-seeking attempts by 
adjacent local authorities to levy benefits from Yangshan's development. The maintenance of the dominance of domestic players also stands in contrast with the literature on other Asian peripheral ports where global foreign players have stimulated the emergence of offshore hubs (Slack and Wang,2002). Third, the Shanghai-Yangshan dual hub port exhibits important differences with generic models due to the development of activities other than sole transshipment, notably in the manufacturing and tertiary sectors, and to the connection of the new port with the hinterland through logistics regionalization.

The case of the Shanghai-Yangshan dual hub port thus contributes revisiting existing literatures about global ports and global cities while providing new insights about the urbanport trajectories of maritime cities in Asia and the rest of the world. The first contribution is the confirmation that the evolution of port, transport, and logistics activities not only illustrates but directly contributes to the evolution of cities and urban systems. This infers that Shanghai's rapid globalization would not have been possible without a gradual improvement of its capacity to move cargo locally and across the Yangtze corridor, as its economic base remains specialized in transport and manufacturing functions. Such an outcome stands in contrast with a general belief that large global cities would (and should) get rid of their physical functions in order to realize a successful transformation into higher-valued, more knowledge-based activities associated with a role as a global command and control centre. The second contribution is that conversely, deviations from general models of port system evolution were mostly caused by the specific local urban and political context. Efforts to transform Shanghai into a global city gave precedence to certain areas that pure physical and economic factors may not have predicted. Rather than the shift of modern terminals towards the already established and well accessible port of Ningbo, preference was given to Yangshan island, in closer proximity to Shanghai, notwithstanding additional costs required in bridge connection. Hence ideal-typical sequences of port system development cannot fully explain the Shanghai-Yangshan case without the inclusion of urban factors. Maintaining new port development within Shanghai's close proximity despite inherent costs and administrative tensions thus translated the will to create a polycentric yet more compact multifunctional and multilayered gateway centered upon Shanghai. The decisive role of the central government in such processes adds to the originality of the Shanghai-Yangshan case compared with other examples of new port development in Asia.

\section{Acknowledgements}


This research was supported by the Natural Science Foundation of China (Project no. $41171108)$.

\section{References}

Airriess, Christopher, "The regionalization of Hutchison Port Holdings in Mainland China," Journal of Transport Geography, 9, 4: 267-278, 2001.

Baird, Alfred J., "Global strategic management in liner container shipping," in: Handbook of Container Shipping Management, 1, Bremen: Institute of Shipping and Logistics, 2003.

Bird, James, The Major Seaports of the United Kingdom. London: Hutchinson, 1963.

Cai, Jianming and Victor F.S. Sit, "Measuring world city formation: The case of Shanghai," The Annals of Regional Science, 37, 3: 435-446, 2003.

Comtois, Claude, "The integration of China's port system into global container shipping," Geojournal, 48, 1: 35-42, 1999.

Cullinane, Kevin, "The container shipping industry and the impact of China's Accession to the WTO," Research in Transportation Economics, 12, 1: 221-245, 2005.

Cullinane, Kevin, Yahui Teng, and Teng-Fei Wang, "Port competition between Shanghai and Ninbgo," Maritime Policy and Management, 32, 4: 331-346, 2005.

Cullinane, Kevin, and Dong-Wook Song, Asian Container Ports: Development, Competition and Co-operation. Basingstoke: Palgrave-Macmillan, 2007.

Ducruet, César, Sung-Woo Lee, and Adolf Ng, "Centrality and vulnerability in liner shipping networks: Revisiting the Northeast Asian port hierarchy," Maritime Policy and Management, 37, 1: 17-36, 2010.

Ducruet, César, Stanislas Roussin, and Jin-Cheol Jo, "Going West? Spatial polarization of the North Korean port system," Journal of Transport Geography, 17, 5: 357-368, 2009.

Ducruet, César, Luis de Carvalho, and Stanislas Roussin, "The flight of Icarus? Incheon's transformation from port gateway to global city," in: Peter V. Hall and Markus Hesse (eds.), Cities, Regions, and Flows, Routledge, 2012.

Fleming, Douglas, and Yehuda Hayuth, "Spatial characteristics of transportation hubs: Centrality and intermediacy," Journal of Transport Geography, 2, 1: 3-18, 1994.

Frémont, Antoine, and César Ducruet, "The emergence of a mega-port: The case of Busan, from the local to the global," Tijdschrift voor Econ. En Soc. Geografie, 96, 4: 421-432, 2005.

Hall Peter V. and Wouter Jacobs, "Why are maritime ports (still) urban, and why should policy makers care?," Maritime Policy and Management, 39, 2: 189-206, 2012. 
Haynes, Kingsley E., Yulian Magnolia Hsing and Roger R. Stough, "Regional port dynamics in the global economy: the case of Kaohsiung, Taiwan," Maritime Policy and Management, 24, 1: 93-113, 1997.

Hayuth, Yehuda, "Rationalization and concentration of the U.S. container port system," The Professional Geographer, 40, 3: 279-288, 1988.

Hesse Markus, "Cities, material flows and the geography of spatial interaction: Urban places in the system of chains," Global Networks, 10, 1: 75-91, 2010.

Huang, Yefang, "The growth of global hub port cities under globalisation: The case of Shanghai international shipping centre," International Development Planning Review, 31, 4: 321-344, 2009.

Jacobs, Wouter and Peter V. Hall, "What conditions supply chain strategies of ports? The case of Dubai," Geojournal, 68, 4: 327-342, 2007.

Jacobs, Wouter, César Ducruet and Peter Wubbe De Langen, "Integrating world cities into production networks: the case of port cities," Global Networks, 10, 1: 92-113, 2010.

Jacobs, Wouter, Hans R.A. Koster and Peter V. Hall, "The location and global network structure of maritime advanced producer services," Urban Studies, 48, 13: 2749-2769, 2011.

Lai, Karen P.Y., "Global cities in competition? A qualitative analysis of Shanghai, Beijing and Hong Kong as financial centres," GaWC Research Bulletin, 313, http://www.lboro.ac.uk/gawc/rb/rb313.html, 2009

Lee, Jung-Yoon, and Jean-Paul Rodrigue, "Trade reorientation and its effects on regional port systems: The Korea-China link along the Yellow Sea Rim," Growth and Change, 37, 4: 597-619, 2006.

Lee, Sung-Woo, and César Ducruet, "Spatial glocalization in Asia-Pacific hub port cities: A comparison of Hong Kong and Singapore," Urban Geography, 30, 2: 162-184, 2009.

Lee, Sung-Woo, Dong-Wook Song, and César Ducruet, "A tale of Asia's world ports: The spatial evolution in global hub port cities," Geoforum, 39, 1: 372-385, 2008.

Lemarchand, Arnaud, and Olivier Joly, "Regional integration and maritime range," in: Theo Notteboom, César Ducruet, and Peter de Langen (eds.), Ports in Proximity: Competition and Cooperation among Adjacent Seaports, Aldershot: Ashgate, 2009.

Lu, Chin-Shan, and Ching-Chiao Yang, "Comparison of investment preferences for international logistics zones in Kaohsiung, Hong Kong, and Shanghai ports from a Taiwanese manufacturer's perspective," Transportation Journal, 45, 1: 30-51, 2006. 
Ng, Adolf, "Assessing the attractiveness of ports in the North European container transhipment market: An agenda for future research in port competition," Maritime Economics and Logistics, 8, 3: 234-250, 2006.

Notteboom, Theo, and Jean-Paul Rodrigue, "Port regionalization: Towards a new phase in port development," Maritime Policy \& Management, 32, 3: 297-313, 2005.

Palmer, Sarah, "Current port trends in an historical perspective," Journal for Maritime Research, 1, 1: 99-111, 1999.

Rimmer, Peter, "The changing status of new Zealand seaports 1853-1960," Annals of the Association of American Geographers, 57, 1: 88-100, 1967a.

Rimmer, Peter, "The search for spatial regularities in the development of Australian seaports," Geografiska Annaler, 49, 1: 42-54, $1967 \mathrm{~b}$.

Rimmer, Peter, and Claude Comtois, "China's container-related dynamics, 1990-2005," Geojournal, 74, 1: 35-50, 2009.

Rodrigue, Jean-Paul, and Theo Notteboom, "Foreland-based regionalization: Integrating intermediate hubs with port hinterlands," Research in Transportation Economics, 27, 1: 19$29,2010$.

San Juan, Thierry, Atlas de Shanghai, Paris: Autrement, 2009.

Slack, Brian, "Containerization, inter-port competition, and port selection," Maritime Policy and Management, 12, 4: 293-303, 1985.

Slack, Brian, and James Wang, "The challenge of peripheral ports: An Asian perspective," Geojournal, 65, 2: 159-166, 2002.

Song, Dong-Wook, "Regional container port competition and co-operation: The case of Hong Kong and South China," Journal of Transport Geography, 10, 2: 99-110, 2002.

Taaffe Edward, Richard Morrill, and Peter Gould, "Transport expansion in underdeveloped countries: A comparative analysis," Geographical Review, 53, 4: 503-529, 1963.

Van der Lugt, L. and Peter Wubbe De Langen, "Ports as locations for logistics activities," Journal of International Logistics and Trade, 3, 2: 59-72, 2005.

Veenstra, Albert, and Theo Notteboom, "The development of the Yangtze River container port system," Journal of Transport Geography, 19, 4: 772-781, 2011.

Wang, James, "A container load center with a developing hinterland: A case study of Hong Kong," Journal of Transport Geography, 6, 3: 187-201, 1998. 
Wang, James, and Michael Cheng, "From a hub port city to a global supply chain management center: Case study of Hong Kong," Journal of Transport Geography, 18, 1: 104$115,2010$.

Wang, James, Adolf Ng, and Daniel Olivier, "Port governance in China: A review of policies in an era of internationalizing port management practices," Transport Policy, 11, 3: 237-250, 2004.

Wang, James, and Daniel Olivier, "Port - FEZ bundles as spaces of global articulation: The case of Tianjin, China," Environment and Planning A, 38, 8: 1487-1503, 2006.

Wang, James, and Daniel Olivier, "L'administration des ports et la relation ville-port en Chine," Cahiers Scientifiques du Transport, 44: 25-54, 2003.

Wang, James, and Brian Slack, "The evolution of a regional container port system: The Pearl River Delta," Journal of Transport Geography, 8, 4: 263-275, 2000.

Weber, Joe, "Diverging narratives: Evaluating the uses of the ideal-typical sequence of transport network development," Journal of Geography, 103, 5: 211-217, 2004.

Wei, Yehua Dennis, and Chi Kin Leung, "Development zones, foreign investment, and global city formation in Shanghai," Growth and Change, 36, 1: 16-40, 2005.

Wu, Fulong, "The global and local dimensions of place-making: Remaking Shanghai as a world city," Urban Studies, 37, 8: 1359-1377, 2000.

Yan, Zhongmin and Jianzhong Tang, "Areal expansion of urban Shanghai," Geojournal, 21, 1-2: 57-64, 1990.

Yap, Wei-Yim, and Jasmine Lam, "Competition dynamics between container ports in East Asia," Transportation Research Part A, 40, 1: 35-51, 2006.

Yeung, Yue-Man, and Xiaojian Li, "Bargaining with transnational corporations: The case of Shanghai," International Journal of Urban and Regional Research, 23, 3: 513-533, 1999.

Yusuf, Shahid, and Weiping Wu, "Pathways to a world city: Shanghai rising in an era of globalization," Urban Studies, 39, 7: 1213-1249, 2002. 
Table 1: Construction phases of Yangshan port

\begin{tabular}{|c|c|c|c|c|c|}
\hline Phase & Time range & $\begin{array}{c}\text { No. } \\
\text { berths }\end{array}$ & $\begin{array}{c}\text { Ton } \\
\text { grade/tons }\end{array}$ & $\begin{array}{c}\text { Quay } \\
\text { length } \\
(\mathrm{m})\end{array}$ & $\begin{array}{c}\text { Handling } \\
\text { capacity (million } \\
\text { TEUs) }\end{array}$ \\
\hline I & $2002-2005$ & 5 & $70-100 T$ & 1,600 & 2.5 \\
\hline II & $2005-2006$ & 4 & $70-100 T$ & 1,400 & 2.1 \\
\hline III & $2006-2010$ & 7 & $70-150 T$ & 2,600 & 4.7 \\
\hline IV & $2011-2020$ & 14 & $70-150 T$ & 4,400 & 5.7 \\
\hline
\end{tabular}


Figure 1: Spatial evolution model of a container port system

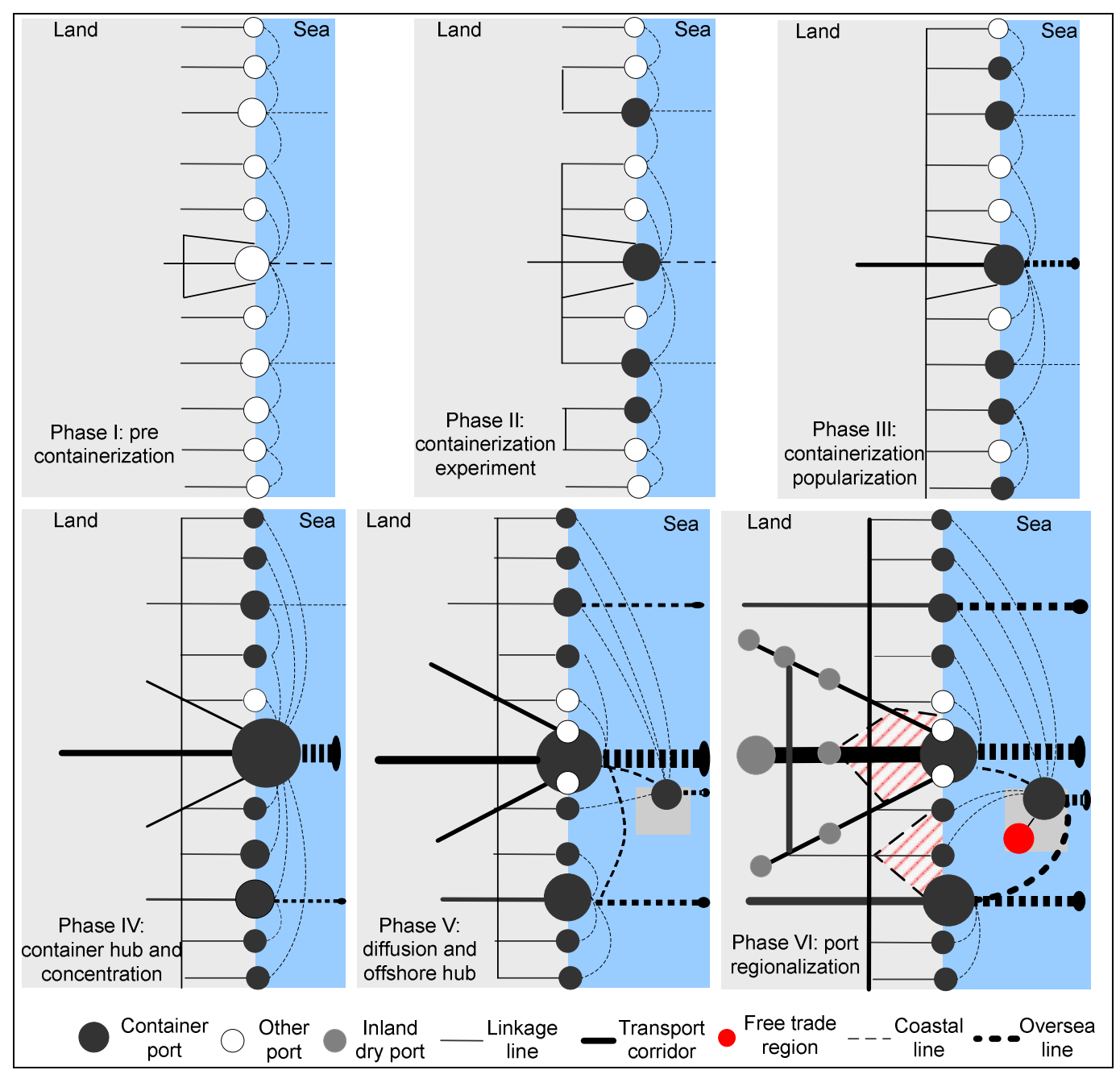

Source: modified from Notteboom and Rodrigue, 2005 
Figure 2: Evolution of the Yangtze River Delta port hierarchy, 1979-2010

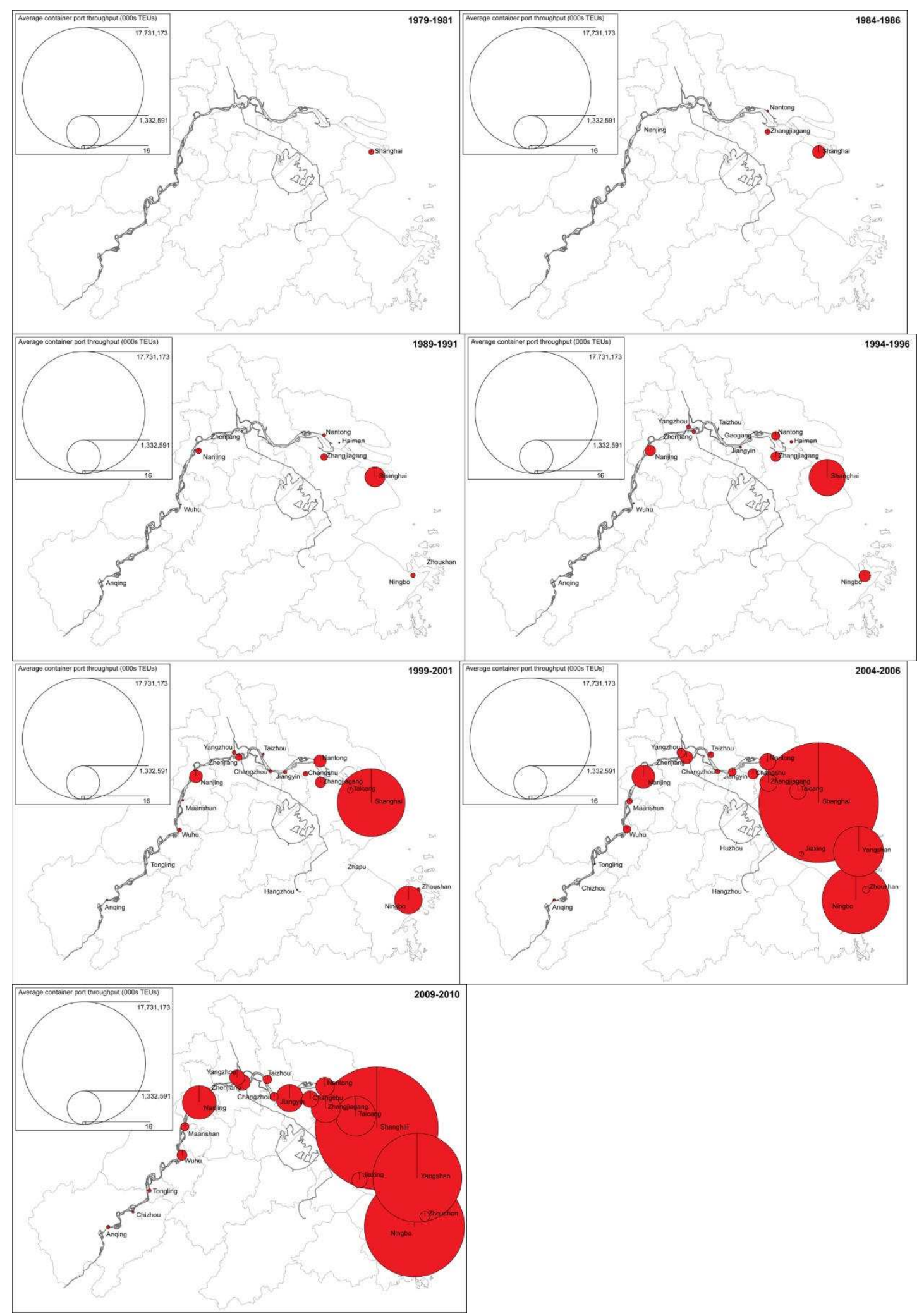

Source: own realization based on Yearbook of China Transportation \& Communication 
Figure 3: Container traffic evolution, 1979-2010

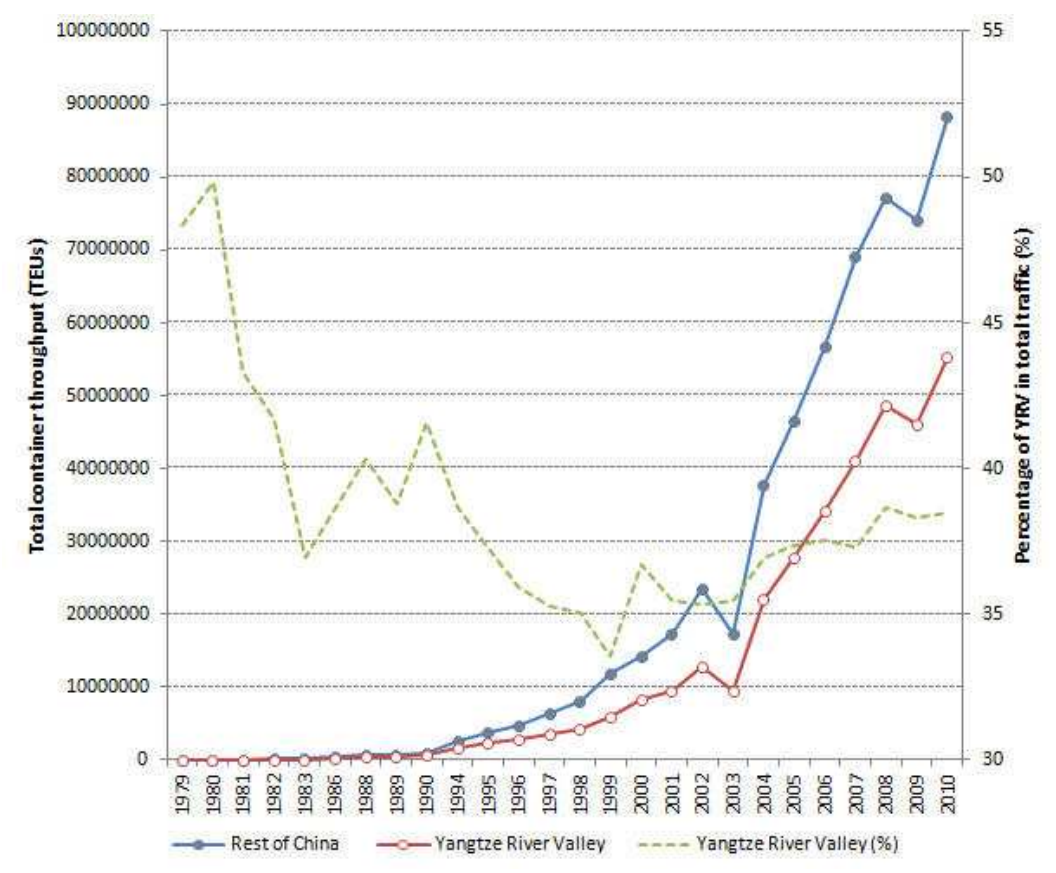

Source: own realization based on Yearbook of China Transportation \& Communication

Figure 4: Number of container ports and traffic concentration, 1979-2010

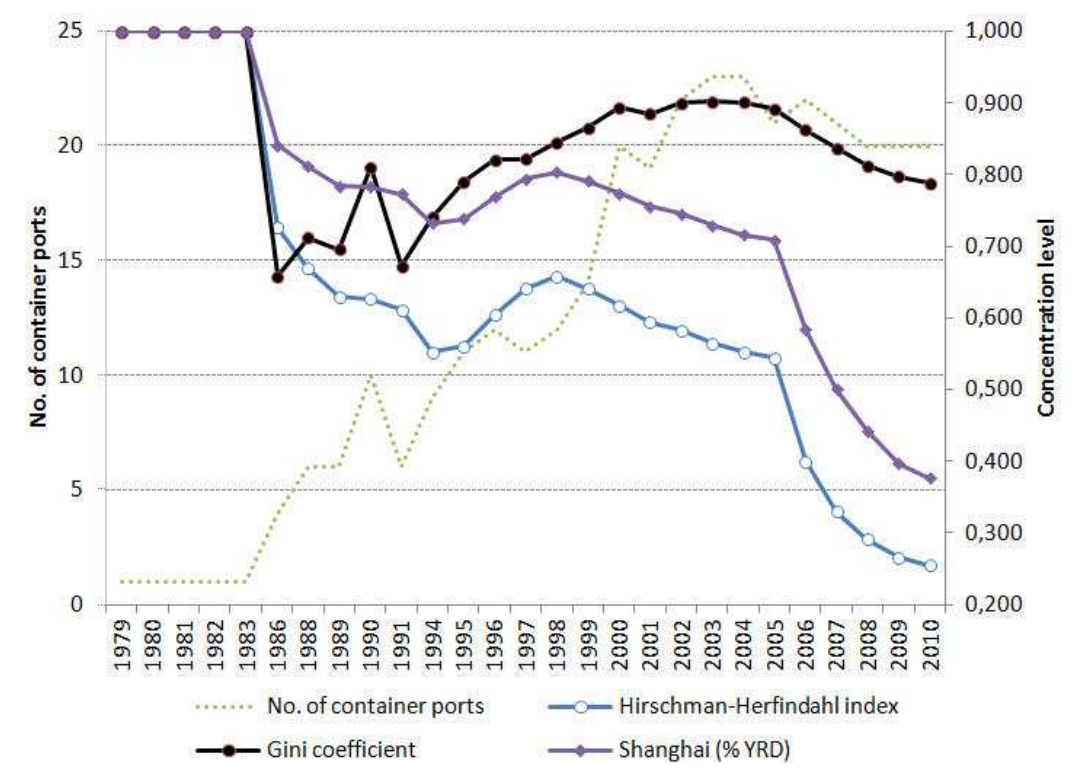

Source: own realization based on Yearbook of China Transportation \& Communication 
Figure 5: Feeder traffic between Yangtze River ports and Shanghai

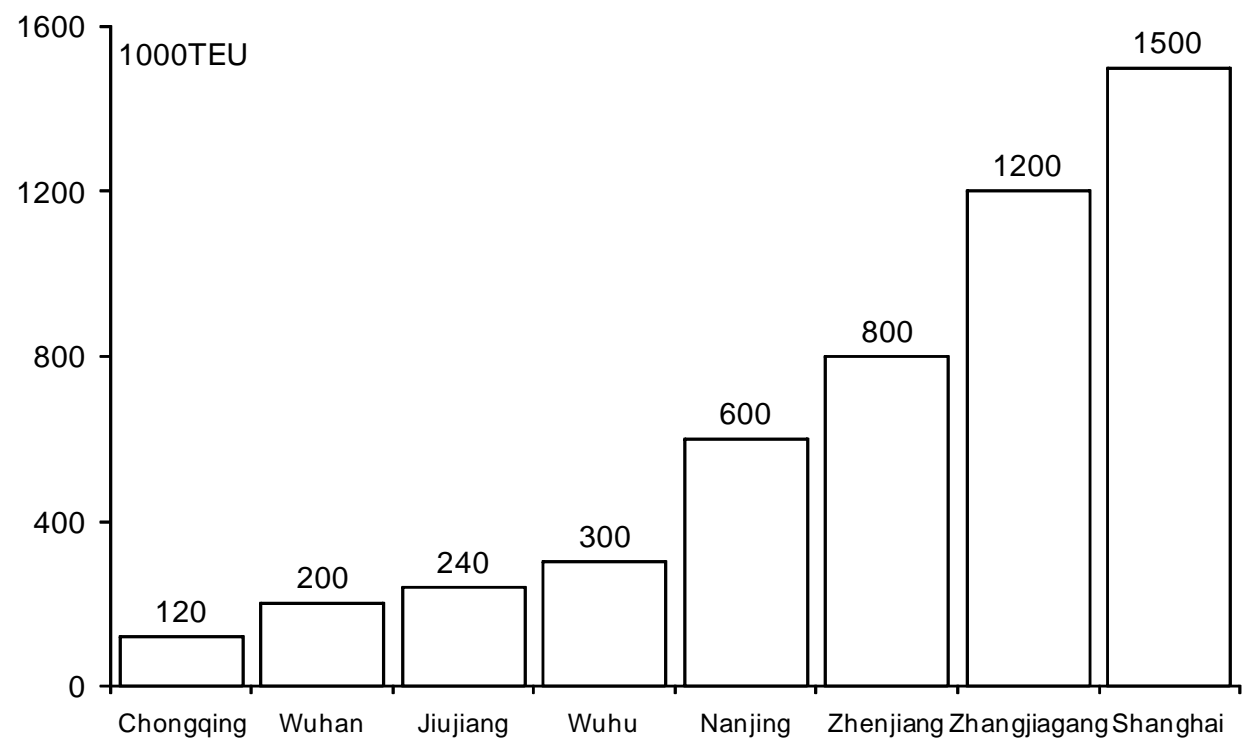

Source: own realization based on Yearbook of China Transportation \& Communication 
Figure 6: Governance structure of Yangshan port

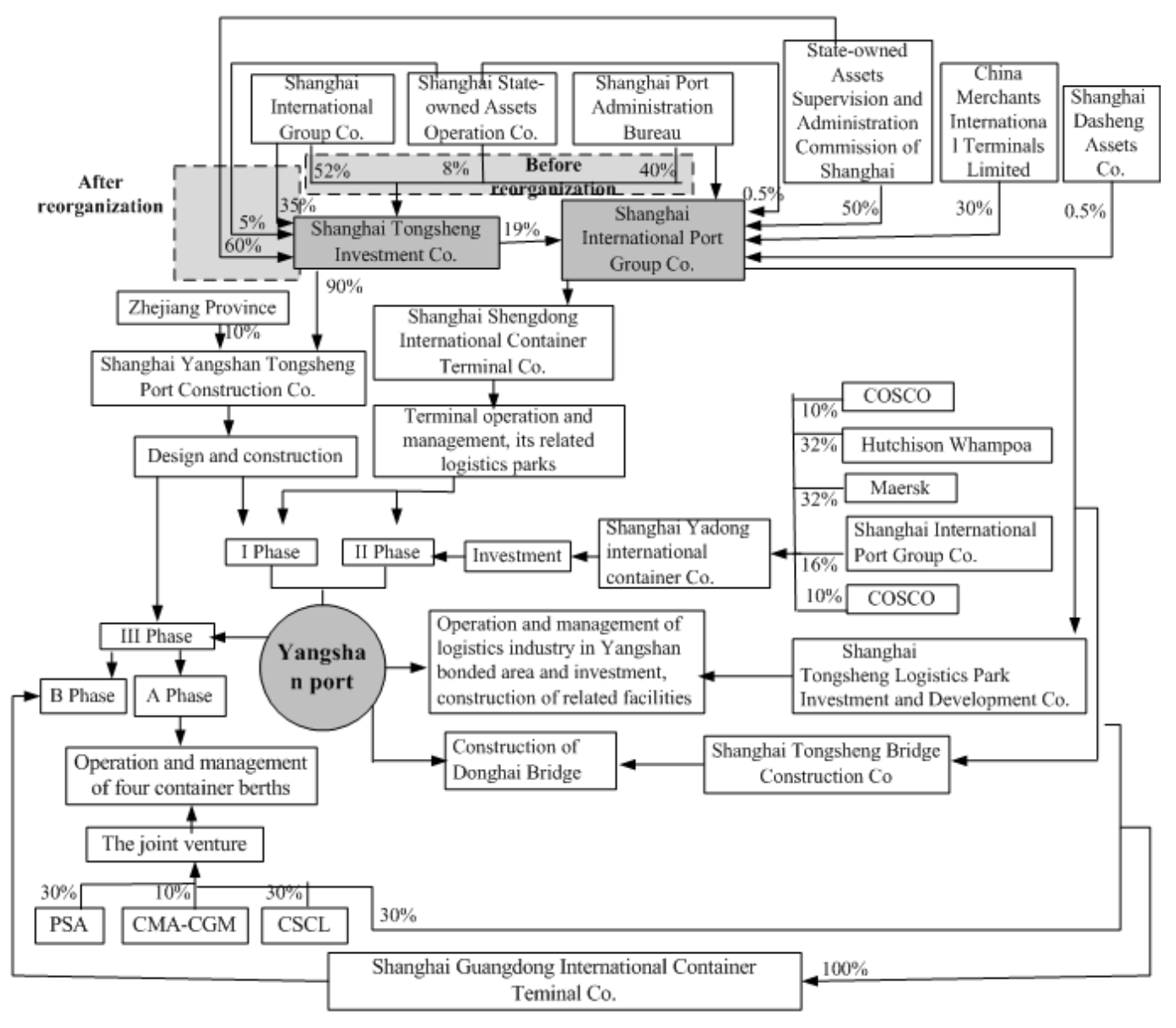

Source: own realization based on various reports 
Figure 7: Container traffic evolution at Yangshan port since May 2006
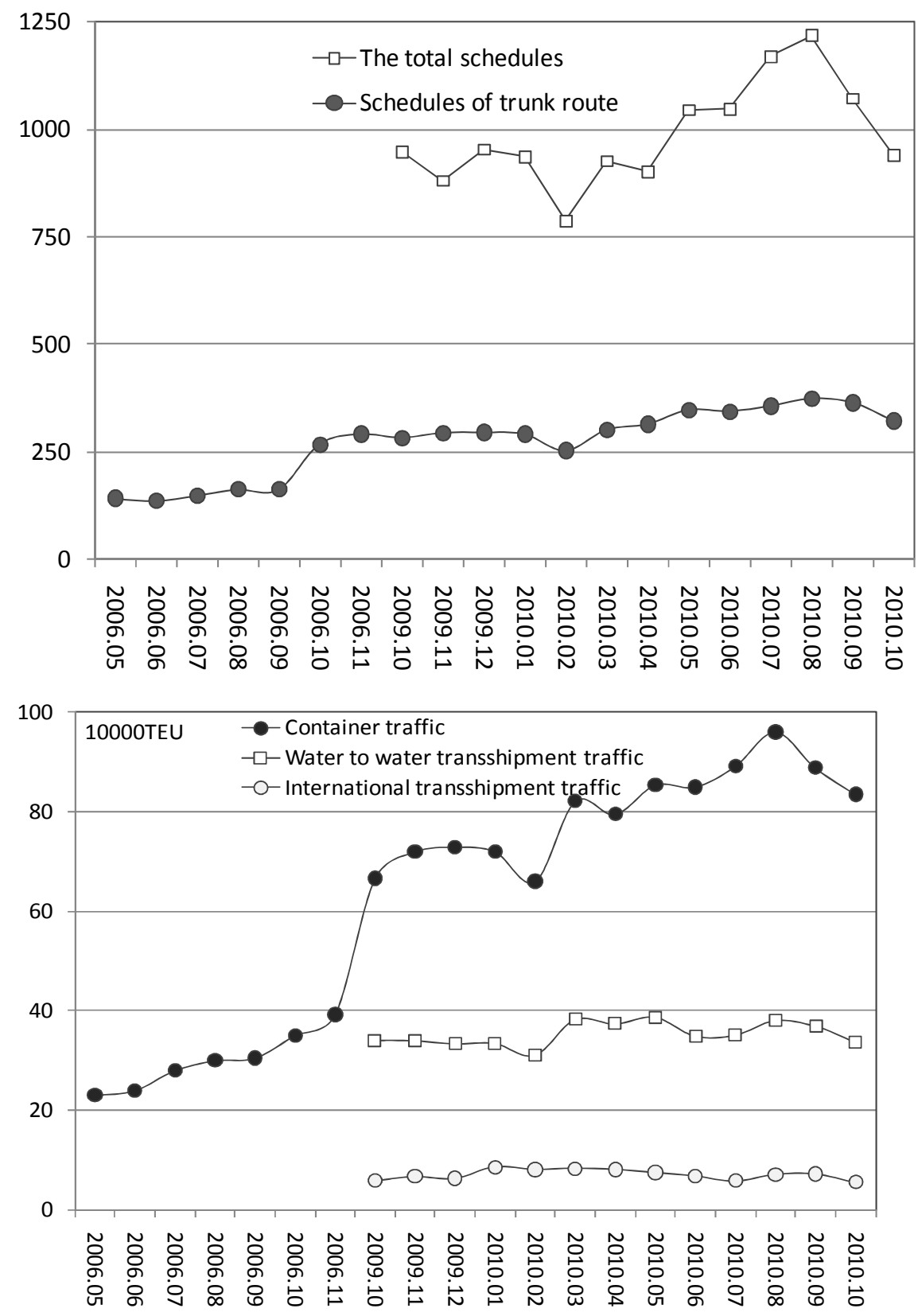

Source: own realization based on Yangshan Port Authority (http://www.ysftpa.gov.cn) 
Figure 8: Container traffic evolution at Shanghai, Yangshan, and Ningbo

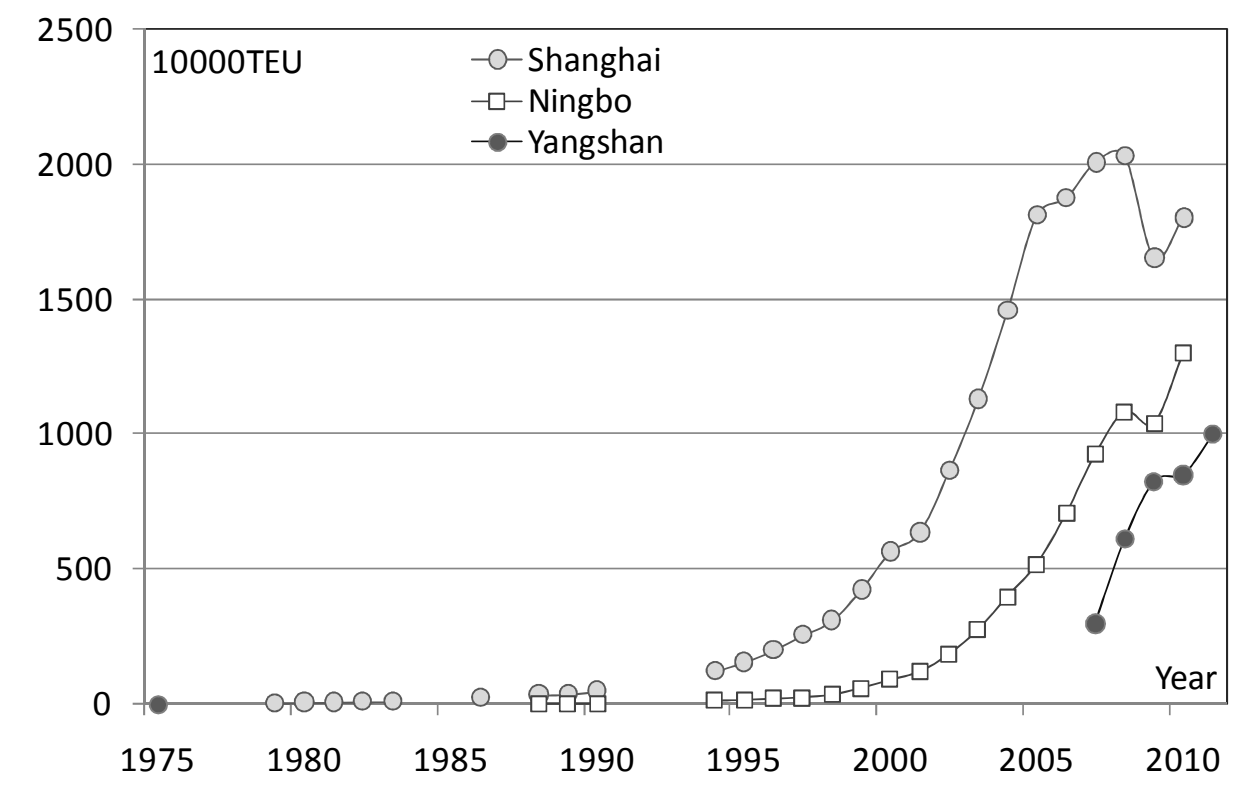

Source: own realization based on Yearbook of China Transportation \& Communication

Figure 9: Container traffic by truck over Donghai Bridge, 2006-2009

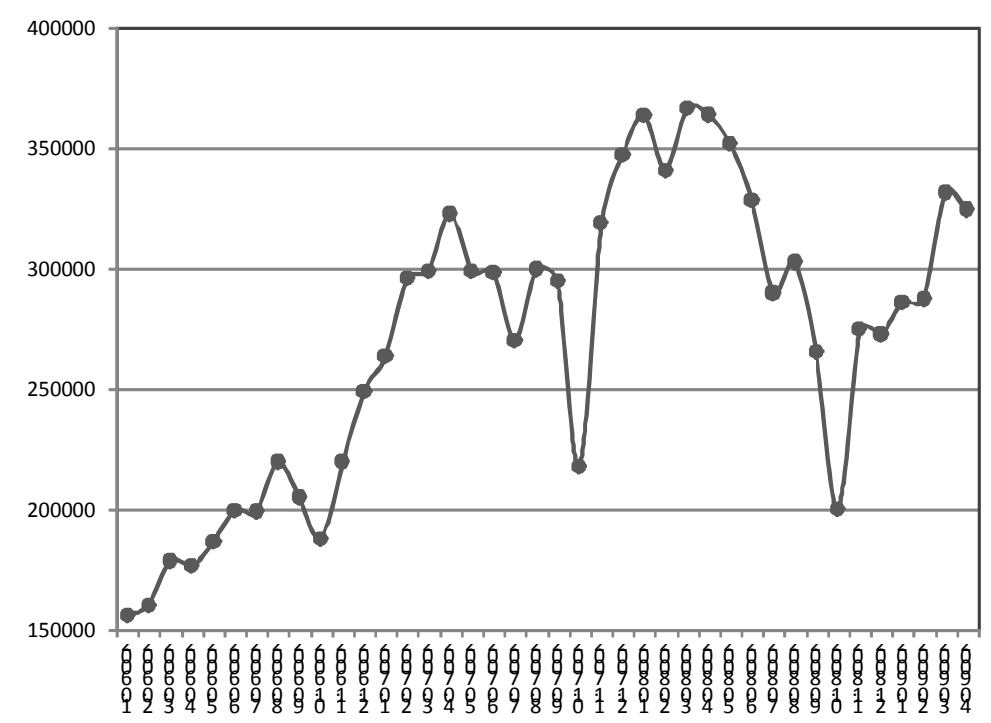

Source: own realization based on Shanghai Free Trade Zones Administration (http://www.ysftpa.gov.cn) 
Figure 10: Urban and transport land-use in Shanghai

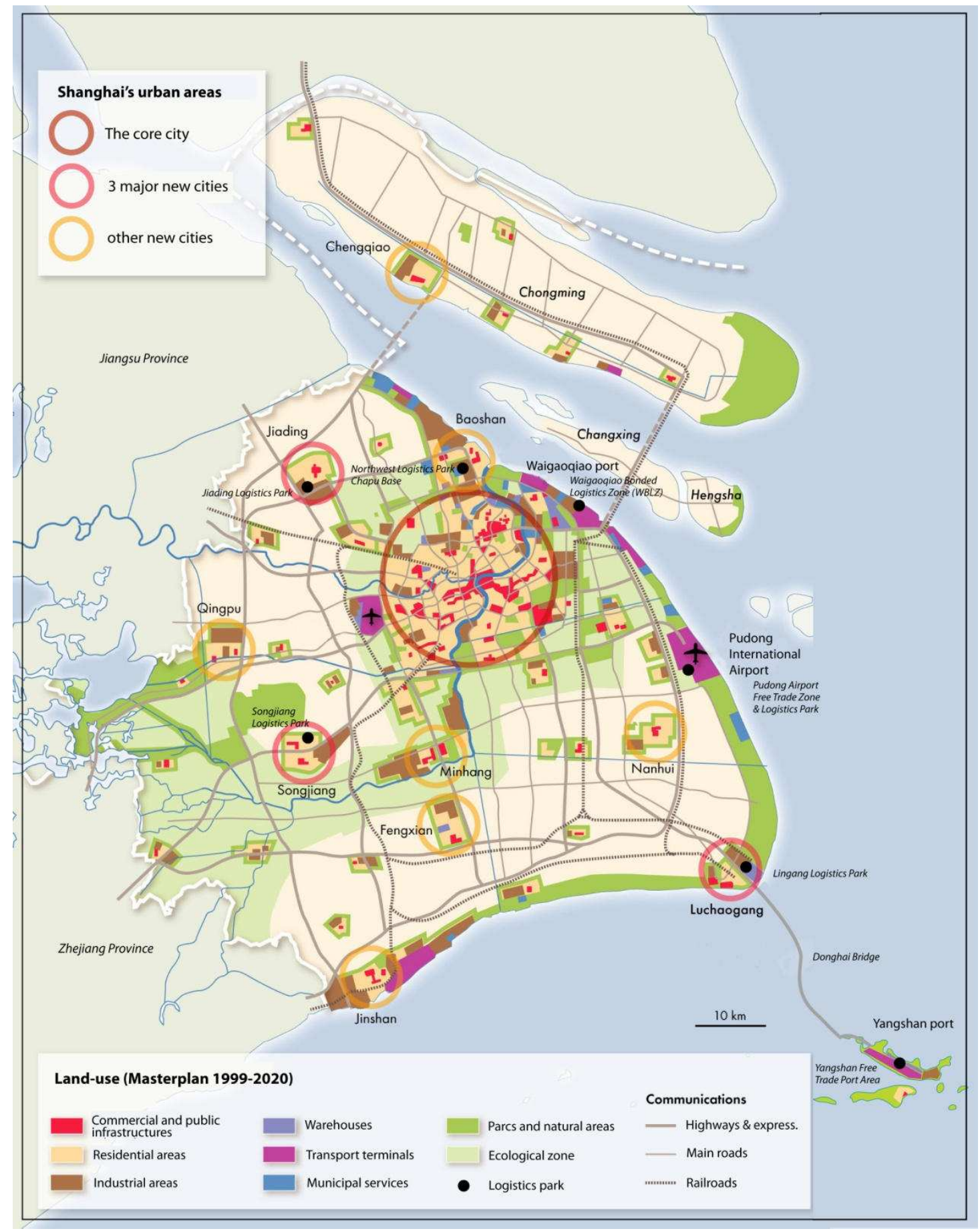

Source: modified from San Juan (2009) 